\title{
Belorussian versus Ukrainian: Delimitation of Texts before A.D. 1569
}

\author{
BY
}

\section{GEORGE Y. SHEVELOV}

If a problem is debated without solution for many decades it can usually be inferred that it had been defined inappropriately to begin with. Instead of continuing along the same track it is wiser to revise the original premises.

The long-lasting controversy on the delimitation of Belorussian $(\mathrm{Br})$ from Ukrainian $(\mathrm{U})$ texts of the middle period (late 14th through the 17th century) seems to be a case in point. Without going into the time gone-by when $\mathrm{Br}$ was considered by some scholars (e.g. Ohonovs' $\mathrm{kyj}^{1}$ ) to be but a dialect of $U$ and without offering a bibliographical survey ${ }^{2}$ I shall limit myself to mentioning here those who have taken part in the discussion. Some have contributed special studies, other have touched on the problem in a broader context (usually in histories of the two standard languages), and still others have compiled lists of texts claimed to be specifically $\mathrm{U}$ or $\mathrm{Br}$. Ja. Karski, P. Žytec'kyj, V. Lastowski, H. Omel'čenko, Je. Tymčenko, I. Ohijenko, A. Žurawski, L. Sakun, L. Humec'ka, B. Strumiński, P. Pljušč, F. Žylko, A. Martel, C. Stang, M. Žovtobrjux, P. Tymošnko - these names come to one's mind - and the list is still, no doubt, far from complete. One must add those who participated in the discussion indirectly, by assigning a specific text to either $\mathrm{Br}$ or $\mathrm{U}$, an apparently innocuous act in itself if done, so to speak, in passing but one which may become fraught with consequences if it so labels a text published reliably for the first time. An example is the publication of 14th and 15th-century charters by V. Rozov, Ukrajins'ki hramoty (Kiev, 1928) ${ }^{3}$ - are all of them Ukrainian? I. Ohijenko introduced the Act and Epistles of Krexiv into the scholarly circuit in a voluminous book entitled Ukrajins'ka literaturna mova XVI st., I. Krexivs'kyj Apostol 1560-x rr. (Warsaw, 1930) - is the text really Ukrainian? I. Bilodid included Hramatyka slovenskaja by I. Uževič in the series Pamjatky ukrajins'koji movy XVII st. (Kiev, 1970) and launched it as 'perša hramatyka vlasne ukrajins'koji literaturnoji movy' (p. v). Is it? Daškevyč published some Turkish diplomatic correspondence dated 1541-1543 as Ukrainian. ${ }^{4}$ Beyond any doubt it is $\mathrm{Br}$. As is generally known, Lastowski had similar claims on the $\mathrm{Br}$ side. $^{5}$

Such 'annexations' probably seem to their perpetrators as important for enhancing the cultural tradition of the given nation, though 
all they actually do is deprive that nation of its real history as its edifice sags or even crumbles under the pressure of these extraneous bodies. This is what has happened to the early history of the Russian language: it is heavily distorted and hardly exists as a scholarly whole because of the mass inclusion of non-Russian data into it. It is maintained simply as an uncritically accepted set of internally contradicting clichés held together by the force of an extrascholarly pressure. Such a situation can just as easily prevail in the histories of the $\mathrm{U}$ and $\mathrm{Br}$ languages and literatures of the middle period if nationalistic gluttony is not exposed as one of the seven deadly sins. The self-presented gifts at the expense of the neighbor are more perilous than the dona Danaorum.

It is this danger of anarchy in the history of the Middle Ukrainian (MU) and Middle Belorussian (MBr) languages which makes it incumbent upon us to return to the century-long discussion and to attempt a revised view at it and at its subject. It seems that what is needed - apart from good will which we must assume is present on both sides - is not a revolution in approach but just greater precision in singling out the various facets of the problem. There are at least three points of view which can be applied to the delimitation of $\mathrm{Br}$ and $U$ texts of the middle period and it is vitally important to keep them apart. The texts can be judged and classified from the viewpoint of the history of literature(s); of the history of the standard language(s); and of the history of the spoken language(s). Not that these criteria are new. One may find some rudimentary references to them, e.g. in Ohijenko, ${ }^{6}$ in Žurawski, ${ }^{7}$ a.o. But it seems that the distinction between the three has not been adhered to strictly enough. ${ }^{8}$

1. Literary problems can only be touched upon in this article. The fundamental fact is that the Belorussians and most of the Ukrainians (all except Bukovyna and Transcarpathia) lived in essentially one country, adhered to the same religion with the same church language, and had common interests and common enemies (and nothing is more unifying than common enemies!). There were no obstacles to the unimpeded circulation of ideas, books, and people. Concerning the last, the participation of the Belorussians in the population movements to the south, especially along the Dnieper, in the Reconquista of the territories below Kiev, which started in the late 15 th and early 16 th century, is well known, although the part they played in the formation of the Cossacks and the military and political center in and around Sič has not been emphasized sufficiently. No less known - and no less important - was the constant influx of intellectuals from the Ukraine to Vil'na (Vilnius), the political capital and the cultural center of the Grand Duchy of Lithuania. Even intellectuals from the properly Polish part of the country, i.e. mainly Galicia, were attracted to Vil'na and not to their 'own' political capital, Cracow, which alienated them by the differences in religion and cultural tradition, as did even more the Volhynians and the Kievans. There were no animosities among the Ukrainians and the Belorussians and I am not aware of any utterances by a contemporary which would stress the distinction between the two nationalities. 
Under these conditions one must speak of on e literary process. Naturally, writers may be classified by the place of their birth, education, or activity wherever there is sufficient information on such details. But such external criteria would be artificial and indeed superfluous for the understanding of the literature. And what if the same author wrote a book in the Ukraine and another in Belorussia? It would be rather ludicrous to cut his work in parts and to assign one part to the Ukrainian literature and the other to Br. Exceptions should be made for those works which only existed in manuscript form and where the available data suggest that they were used only regionally in one or the other country. This seems, e.g., to apply to some clearly $\mathrm{Br}$ texts in the Poznan collection of tales (Povest' o Tryščane, Istoryja o Atyli a.o.), - at least until their circulation in the Ukraine is demonstrated.

The literary process of the time may be most adequately presented as a history of interconnected local cultural centers such as Vil'na, Zabludaw, Ostrih-Derman', L'viv, later Orša-Kucein, etc. Then the differences between a $\mathrm{Br}$. history of literature and a $\mathrm{U}$ history of literature for the period under discussion would be not so much in the scope of the authors, works, and styles analyzed as in a different degree of attention paid to the history of such local cultural centers. ${ }^{9}$

2. The situation is similar but more complicated with the standard language or, more accurately, standard languages: the ecclesiastic and the secular (with some compromises between the two). The ecclesiastic language remained essentially Church Slavonic (ChS1), not only in church service books but also in the original writings; it is enough to refer, e.g., to the Metropolitan Misail's Poselstvo do Papeža Siksta IV (1470s) or to the epistle to the Patriarch of Constantinople concerning Jonah Hlezna (ca. 1490). ${ }^{10}$ Local features crept into those texts, of course, but inadvertently. They can be exposed by the language historian as a superstratum over the ChS1 foundation (as is done for material written before the 14th century) and, as expected, they are mostly either $\mathrm{U}$ or $\mathrm{Br}$. But a third ingredient may also be found in such texts, and this may be identified as the standard secular language of the country; in fact $\mathrm{Br}$ or $\mathrm{U}$ contributions may be uncovered only under this disguise. This is especially true of texts deliberately aiming at linguistic compromise, such as the Presopnycja Gospel (1556-1561). It is a simplification when students speak of a compromise between $\mathrm{ChSl}$ and $\mathrm{U}$ in this and similar texts. Actually Abbot Hryhorij and Myxajlo Vasyl'ovyč from Sjanik (Sanok) strove for a new unity of ChSI and secular traditions, not for the use of the U vernacular. U features are present in this text but only behind the façade of the standard secular language. It would be interesting to know if the same applies (with a quite different ratio of components) to $\mathrm{Br}$ features in Skaryna's translations.

This brings us to the question of the nature of that standard secular language, which conventionally may be called Ruthenian (Rth). If we stay within the period ending at 1577, Karski's characterization of this language as $\mathrm{Br}$ (drawn in 1893!) - if one disregards external 
influences, mainly lexical and syntactic Polonisms - is basically correct. ${ }^{11}$ One can go even farther and speak of its North Central $\mathrm{Br}$ dialectal basis. The qualification introduced by Stang that at the earliest decades of its formation in the chancery of the Grand Dukes of Lithuania there was a U (later Polissian) element in that language $^{12}$ is practically of minor importance because the trend was not continued after the late 15th century and, in addition, very few $\mathrm{Br}$ ancl $\mathrm{U}$ manuscripts are extant from this earlier time. The view that $\mathrm{Br}$ and $\mathrm{U}$ were consciously synthesized in that language ${ }^{13}$ is inadequate. There were no conditions for such a synthesis at the Vil'na princely chancery where that language was given shape. Paraphrasing the common saying in this case the rule Cuius caput eius linga applied. Moreover, and more important, there are no $U$ features, except for the first formative decades, in the texts written in and around Vil'na at the time under discussion.

The standard secular language, Rth, being thus $\mathrm{Br}$, the Ukrainians in their use of it now and then introduced some $U$ features precisely as they had done in ChSl. In such cases one could speak of Ukrainianisms in that language and one could apply the same method for extracting $\mathrm{U}$ features as is applied to ChSl texts. But the actual situation is much more complex, because the standard secular language of the time, when used outside of the region of its rise, i.e. outside of Belorussia proper, not only admitted, but even in most cases required, certain fairly regular substitutions. We are well aware of them in orthography and phonetics; whether they extended to vocabulary is not known, in any case there they were not striking. ${ }^{14}$

The inviting analogy is that with English-speaking countries of our time. A British English text coming to America is adapted orthographically: valour becomes valor, organisation is transformed into organization, etc. What is more important, the invisible standards of pronunciation differ strongly as, say, the vowel in the verb to know. The semblance of unity is maintained by the conservatism of the spelling alone.

The conservatism of orthography was also of major importance in $R$ th (and it is in this only - and even here but partially - that it continued the tradition from before the 14th century). The most striking features of $\mathrm{Br}$ pronunciation were not admitted into writing: akan'e, cekanne-dzekanne, nor were such U peculiarities as $u$ from $o$ and $e$ in the newly closed syllables (Modern $U$ i) and the so-called new $\check{e}$. The latter, widely spread in Old U texts of the 12th through the 14th century, was eliminated as a rule in later texts and replaced by $e$ in disregard of the pronunciation. ${ }^{15}$ But the scope of admitted and required substitutions in spelling was broader than in Modern English and by no means limited to unessential orthographic conventions. I shall go further into these substitutions below (in section 3 ). Here only two facts should be brought to the attention. One is the regularity of these substitutions. It is the merit of Aničenka to have shown how systematically they were introduced in $\mathrm{U}$ copies of $\mathrm{Br}$ texts such as Žuhaj's of Skaryna's Bible or the 'Kievan' copy of the Lithuanian Statute (pp. 136-43 of his book cited in note 2). ${ }^{16}$ The 
second is - and this is rarely realized - that the substitutions were of two kinds: not only U vs. Br but also U vs. Polissian and Polissian vs. the other two. These were the years in which the bilateral erosion of Polissian dialects into $\mathrm{Br}$ proper in the north and Ukrainian proper in the south was in progress, but the Polissian dialects were still a unit (although already a shrinking one) strong enough culturally to develop their own set of substitutes, most strikingly in the case of $\check{e}$ : while the standard secular language of the capital and the regions around it admitted the use of $e$ instead of $\check{e}$ in all positions, the Polissian did not allow such a replacement in the stressed syllable and $U$ proper did not allow it at all. There are also indications that even when $\check{e}$ was under stress and was so written, its sound value was [e] in Br proper, [ie] in Polissia, and [i] in U proper.

The inference from the above is that $\mathrm{Rth}$ was the common secular language for both Belorussians and Ukrainians, just as ChSl was their common standard ecclesiastic language. The admitted sets of substitutions, extremely useful as they are in the localization of texts, do not amount to a synthetic superunit or two or three literary languages. In the histories of the $\mathrm{Br}$ and $\mathrm{U}$ literary languages it should be considered as on e language, the one shaped in North Central Belorussia. The difference between its treatment in the histories of the $\mathrm{Br}$ and $\mathrm{U}$ literary languages is to be in the emphasis on its basis or on specific sets of substitutions. If one speaks of the $U$ literary language of the 16th century (within the period under consideration) whether deliberately or inadvertently one uses an ambiguous term. It is correct if what is understood is Rth as used by the Ukrainians; it is misleading if what is meant is a standard language based on U dialects and shaped by the Ukrainians for their own use. Such a U literary language did not exist at that time.

3. Contrary to the unity of the standard written language(s) there was beyond any doubt no unity in the spoken language. Furthermore, it was not just an agglomeration of regional dialects either. Such dialects of course existed but they were clearly subordinate to more general patterns: that of $\mathrm{Br}$ and that of $\mathrm{U}$, with the transitional Polissian pattern. The historian of phonology, morphology, syntax and vocabulary of either language should not be deceived by the relative uniformity of the written language. It is for him that the delimitation of texts is of vital importance.

Today we are unable to carry out this delimitation by basing it on differences in vocabulary. But we cannot follow Žurawski (op. cit., p. 81) when he says that the general delimitation will be possible only after the appearance (vyxad) of Old $\mathrm{Br}$ and Old $\mathrm{U}$ historical dictionaries. ${ }^{17}$ This is putting the cart before the horse. In order to have such dictionaries one has first to know which texts are to be used in which. The delimitation obviously must precede the compilation. The subsequent dictionaries will probably require minor corrections of the preliminary classification but these will hardly be sweeping.

Fortunately the delimitation of texts is in principle possible today. It can be performed for a great many texts on the basis of phonetic 
and orthographic peculiarities. The very principle of $s u b s t i t u t i$ on is rooted in the differences between the two languages. In addition, there are in most texts both handwritten and printed d e partures from the established general standard (including the admitted substitutions) due to insufficient training or slips of the writer, scribe, or printer which reflect the spoken language.

Before we proceed to a brief examination of the most typical substitutions and departures which make the localization of texts possible it is worth mentioning that the location of a text compilation is of lesser importance than intrinsic linguo-orthographic criteria. A U scribe could have worked in Vil'na, a $\mathrm{Br}$ monk could have written a text in a monastery near L'viv. Some texts written in the Ukraine and even in Moldavia are linguistically $\mathrm{Br}$, e.g. the Luc'k charter of 1388 , the note of Ştefan of Moldavia to Prince Alexander of $1499,{ }^{18}$ the above mentioned Turkish diplomatic correspondence of 15411543 written in the lower reaches of the Dniester, etc.

The set of substitutions accepted in writing as we know it now was as follows:

1) The treatment of $\check{e}$. As pointed out above, three patterns existed: $\check{e}>e$ in any position in $\mathrm{Br}$ proper; $\check{e}>e$ if unstressed only, in Polissian; $\check{e}$ kept intact in U proper. ${ }^{19}$ To exemplify: mésto - mestá, město - mestá, město - městá resp. The exceptions in U proper and Polissian with $e$ instead of the stressed $\check{e}$ in words of the type terpénie have been discussed above. They do not make these texts $\mathrm{Br}$ or mixed. In many texts the stressed $\check{e}$ was reflected as $e$ after $j$ (e.g. priexala, doexati in the Peresopnycja Gospel, pp. 82, 98, 89 resp.). It obviously was considered elegant to write $e$ in the words hrěx (hrešniki, Persopn. Gosp., 90), čelověk (človecy, Kamjanka Buz'ka Gospel, 1411), and nedělja (e.g. in Odrexova charter, mid16 th century $\left.{ }^{20}\right)$. These mannerisms do not place the corresponding text into the group of $\mathrm{Br}$, Polissian, or mixed. They are essentially foreign words sui generis.

2) The treatment of $r$ from older sequences $r b$ and $r b$ between consonants: $r y$ in $\mathrm{Br}$ (and Polissian) vs. $r$ in U, e.g. kryvavyj vs. krvavyj (Modern U kryvavyj is of a later date).

3) The reflex of $e$ in an unstressed position in $\mathrm{Br}$ (and Polissian) is rendered as $e$, in $\mathrm{U}$ as $j a$, e.g. svetyj vs. svjatyj. In this case the $\mathrm{Br}$ orthographic standard was Polissian in origin: there the unstressed $e$ actually had changed into $e$; but it was accepted in $\mathrm{Br}$ proper, where, because of jakan'e, no distinction was made between ' $a$ and 'e in unstressed syllables. Moreover it probably seemed very appropriate in view of the general tendency to eschew any reflection of akan'e in writing, though in $\mathrm{Br}$ proper it actually was hypercorrect.

4) The spelling of $i$ in such oblique cases of the pronoun (u)ves' as usix, usim etc. in $\mathrm{Br}$ (and Polissian) vs. $\check{e}$ in $\mathrm{U}$, a morphologically conditioned development in $\mathrm{Br}$ ('adjectivization' of the pronominal paradigm).

5) $\mathrm{Br}$ (and Polissian?) $u$ vs. $\mathrm{U} o$ in adverbs ending in $\mathrm{Br}$ in -kule / -kul', -tule / -tul' vs. -kole / kol', -tole / tol' in U, cf. Modern Br adkul', dakul' - Modern U zvidkíl' / zvidkiljá. 
Less consistently applied were the following substitutions:

6) $\mathrm{Br}$ (and Polissian) spelling of $o$ after postdentals vs. U more frequent use of e, e.g. in $\mathrm{Br}$ texts žona, in U texts more often žena. This difference is due partly to a stronger adherence by $U$ scribes to church spelling (in its Euthymian guise, see below) and partly to the fact that many - but not all - areas in the (Southwestern) Ukraine did not develop $o$ in such cases at all.

7) Dispalatalization of $r$ reflected by spellings $r b, r y, r a, r u$ instead of $r b, r i, r j a, r j u$ resp. is typical of $\mathrm{Br}$ (and Polissian) texts and less so of $U$ because in the (Southwestern) Ukraine the dispalatalization of $r$ had not affected most regions at that time. Thus, e.g. Br urad vs. U urjad / urad.

8) The postdentals were dispalatalized in $U$ later (and not in all positions) than in $\mathrm{Br}$ (and Polissian). Therefore spellings of the type żyvyj characterize primarily $\mathrm{Br}$ while in $\mathrm{U}$ one finds both the žyvyj and żivyj types. The more conservative attitude of $U$ scribes could also have played some part here.

9) In the gen $\mathrm{pl}, \mathrm{Br}$ (and Polissian) had only $-e j, \mathrm{U}$ both $-y j$ and $-e j$, e.g. Br nočej vs. U nočyj / nočej. But the situation is complicated by the $\mathrm{ChSl}$ influence, which could result in occasional $-y j$ form in $\mathrm{Br}$ texts also.

As a shibboleth by which $\mathrm{Br}$ texts can be identified as distinct from $\mathrm{U}$ ones specific forms of individual words can be useful: $\mathrm{Br}$ teže 'also' vs. U tyž, Br kažnyj 'each' vs. U koždyj / každyj (Modern $\mathrm{Br}$ taksama, kožny, Modern U tež, kóžnyji21).

The palatalization of consonants before $e$ and $i$ in $\mathrm{Br}$ vs. their nonpalatalization in $U$ was no doubt applied as an orthoepic substitution but with one exception it was not reflected in spelling: by the end of the period under consideration, a new letter 9 developed in $\mathrm{Br}$ from a purely graphic variant of $e$ to denote the non-palatalizing pronunciation of consonants before $e^{; 2} \mathrm{U}$ scribes did not accept the letter because they had no need of it: their consonants were not palatalized in that position in any case.

While the substitutions 1-6 were applied fairly regularly, 7-9 were less so. As distinct from all of them, departures from the accepted spelling should be distinguished. They were never applied systematically; moreover, they clearly were not intended. No text has them consistently. But they crept in time and again as an involuntary tribute to the actual pronunciation. For a student interested in the delimitation of $\mathrm{Br}$ and $\mathrm{U}$ texts they are in some cases no less important than the much more regular substitutions. The following should be watched for:

(1) Akan'e in $\mathrm{Br}$ vs. non-akan'e in U (and Polissian). A good collection of examples in E. Karskij, Belorusy, I, Moscow, 1955, pp. $135 \mathrm{ff}$.

(2) Coalescence of $i$ and $y$ in $U$ (and partly Polissian) vs. their distinction in $\mathrm{Br}$. In principle it was avoided in writing as tenaciously as akan'e. But it was much more difficult to do in the case of $i / y$ : akan'e occurred in unstressed positions only and a verification with the stressed vowel within the inflexional or derivational paradigm in 
most cases allowed the 'correct' spelling to be maintained intact. ${ }^{23}$ Only exceptionally were there words without such an alternation. which would have had to have been memorized. But the coalescence of $i$ with $y$ was total and most $U$ scribes were unable to maintain by memory alone the distinction in spelling which had become dead in the language. Hence the practical importance of this confusion for the identification of $U$ texts, although it clearly never acquired the status of a recognized substitution.

(3) $\mathrm{U}-a$ vs. Br (and Polissian) $-e$ in neut subst of the type U zillja, $\mathrm{Br}$ zélle. The change, dating back in $\mathrm{U}$ to the mid-12th century, was not welcomed into the spelling throughout the entire period under scrutiny and even slips are not too frequent. Often it may be spotted through hypercorrect spellings with $-e$ in the gen sg as in tvoeho začatije (Codex Hankenstein 13th c., quoted from the original manuscript, 83v) or nom/acc pl as in majut imene swoi they have their manors' (Žytomyr ljustracija 154524).

(4) Prothetic $v$ - before stressed o-developed in $\mathrm{Br}$; it is occasionally revealed by spellings of the type $u v$-ozero which the scribes apparently justified by considering $v$ as part of the preposition rather than the noun.

(5) $\mathrm{Br}$ scribes were more inclined than $U$ to replace $i$ by $y$ wordinitially after prepositions ending in a consonant, writing e.g. vynšyx instead of $v(r)$ inšix $r$.

(6) The change $l>w$ after $o$ from $b$ and before a consonant (and in masc sg of the preterit) developed in $\mathrm{Br}$ a little earlier than in $\mathrm{U}$. For the early part of the period under consideration spellings with $v$ may point to the $\mathrm{Br}$ provenance of the text. But the practical value of this feature is minimal because in principle such spellings were carefully avoided.

It should be added, on the orthographic level, that the Euthymian reformed spelling (with the restoration of jus velik and omega, the use of $b$ after all word-final consonants whether palatalized or not, and $b$ after $r$ and $l$ in the words of the type serce, i.e. srbdce, etc.) proved to be quite contagious in the Ukraine but touched Belorussia only superficially. As a rule Euthymian orthography earmarks U texts.

The above sets of substitutions (practiced broadly) and departures (creeping in now and then) make the identification of a text as $\mathrm{Br}$ or as $U$ (or Polissian) feasible and often not difficult at all. Against these sets there can hardly be any doubt as to the $\mathrm{Br}$ character of such tales as Tristan, Guido(n), Attila, Troy, ${ }^{25}$ Strasti Xristovy, ${ }^{26}$ on the Three Kings, ${ }^{27}$ O umučenii Pana našeho Esu Krista, ${ }^{28}$ and most works of the Judaizers, with the possible exception of Sestokryl, Tajnaja tajnyx (Aristotolevy vrata) and the Book of Esther. ${ }^{29}$ These texts are virtually free of any $U$ substitutions and departures.

On the other hand there are texts which are beyond all question $U$, such as the Peresopnycja Gospel 1556-1561 or the Verba Gospel $1560 .^{30}$ But purely $U$ texts are rare and more often than not one has to deal with texts which combine $\mathrm{U}$ and $\mathrm{Br}$ features. Such texts come usually but not always from the Ukraine. 
The mixed $\mathrm{Br} / \mathrm{U}$ character of a text can depend on one of two facts:

(1) Whatever the substitutions were, the official language, the language of the capital, was still sublimated $\mathrm{Br}$. Such a language is endowed with a special prestige and it imposes itself consciously or unconsciously upon the population at large. This was the case of the mid-16th century ljustraciji of the U castles (Arxiv Jugo-zapadnoj Rossii VI, 1 (Kiev, 1887), VII, 1 (1886) and VII, 2 (1890)) inasmuch as they were carried out and written down by the local people and not the central administration; many $U$ charters also have scattered Belorussianisms. Some were introduced by prestige-conscious scribes; others may reflect the oral speech under conditions of migrations of Belorussians to the south mentioned above ${ }^{31}$ and communication with state officials and nobility coming from the north. The prevalence of $\mathrm{Br}$ over $\mathrm{U}$ was particularly strong from the late 15 th century to the end of the period under consideration.

(2) Often texts were copied: in the Ukraine from the $\mathrm{Br}$ original or in Belorussia from the U one. In such copies the scribe introduced features of his own language but as a rule was unable (and probably not really trying) to eliminate all the non-compliant features of the underlying text. Such is probably the case of the Čet'ja of $1489,^{32}$ of the well publicized but unfortunately unpublished U copies of the Skaryna Bible translation, by Vasyl' Žuhaj from Jaroslaw (15681569), by Luka of Ternopil' (1569), by Dmytro from Zin'kiv in Podolia (1575), and perhaps of the Krexiv Apostol referred to above. ${ }^{33}$ Typically, for the period prior to $1569 \mathrm{U}$ copies from $\mathrm{Br}$ originals rather than the reverse are more numerous, again due to the leading political and cultural role played before the Union of Lublin by the (North) Br part of the Great Duchy of Lithuania.

It would be futile to break a lance over the labeling of linguistically mixed texts (unless one set of correspondences clearly prevails) as either $\mathrm{Br}$ or $\mathrm{U}$, if one has in mind historical phonology, morphology or syntax of $U$ or Br. One can only accept their mixed character and work with their Ukrainianisms for the history of $U$ and their Belorussianisms for the history of $\mathrm{Br}$.

The suggested principles of classification will not satisfy those who would like to have all the $\mathrm{U}$ texts neatly delimited from the $\mathrm{Br}$ ones. But the historical reality of the time makes such tidiness unrealizable and a sensible student should not impose his longing for simple order upon the complexity of history, the more so because the suggested classification (or virtually giving it up in some cases) makes it feasible (and realistic) to exploit the data of the texts properly for the construction of a sound history of both $\mathrm{U}$ and $\mathrm{Br}$, without marring it by the presence of extraneous data.

It is not the purpose of this article to give an inventory of the Middle $\mathrm{Br}$ vs. Middle $\mathrm{U}$ texts before 1577 . Yet it seems appropriate to mention that at least for secular texts of the 14 th and 15 th centuries an attempt has been made to compile such an invetory by a group of linguists headed by L. Humec'ka who worked in L'viv on such a partial historical dictionary of the U language. On pp. 23-44 of their Probnyj zošyt (referred to above, note 17) a list of sources classified 
as $\mathrm{U}$ may be found, the remaining ones being relegated to $\mathrm{Br}$. The list is the result of serious and objective research and selection, and on the whole is sound. But time and again it still includes items which, according to the criteria suggested here, should be considered $\mathrm{Br}$. To limit oneself to just an example or two: Charter 29 in Rozov's collection (pp. 53f) with its o in Zudečovoms, $i$ in trimi and random distribution of $\check{e}$ and $e$ in all positions, including accented syllables (vernyj, zěmli, vozrevše, namestrkoms, deti a.o.) cannot be U. ${ }^{34}$ Also $\mathrm{Br}$ are charters 46 (detem, nasledkomъ; hrošej) and 56 (imene 'manor', večne, deti, nalepej; žona, lovčoho; sъ ozeri) from Arch. Sang. ${ }^{35}$ Obviously definitive lists of $\mathrm{U}$ and $\mathrm{Br}$ texts of the 14 th and 15 th centuries are still a desideratum. It is not an easy task and there should and will be some overlappings in the two lists for items of mixed character but we are now in a position to carry it out. A sufficient amount of knowledge has been accumulated for such a performance; what is needed is self-restraint and discipline.

\section{FOOTNOTES}

1) E. Ogonowski, Studien auf dem Gebiete der ruthenischen Sprache, L'viv, 1880 , p. 20.

2) This also has been done several 'times with various degrees of exhaustiveness. See, e.g. A. Žurawski, 'Nekatoryja pytanni belaruska-wkrainskix mownyx suvjazej staražytnaha peryjadu', Vesci AN BSSR (Seryja hramadskix navuk), 1966, 2, pp. 79-81; and U. Aničènka, Bielaruska-wkrainskija pis'mova-movnyja suvjazi, Minsk, 1969, pp. 33-6.

3) The title probably was given not by Rozov, who was in the emigration, but by the editor, A. Kryms'kyj.

4) Ja. Daškevyč, 'Turec'ke dyplomatyčne lystuvannja ukrajins'koju movoju', Slavia, 38, 1969, and 'Turec'ki dyplomatyčni lysty ukrajins'koju movoju z 40-x rr. XVI st.', Slavia, 40, 1971.

5) See H. Omel'čenko, 'Kotri pamjatky naležat' ukrajincjam i kotri bilorusam?', ZIFV, 9, 1926.

6) I. Ohijenko, 'Rozmežuvannja pamjatok ukrajins'kyx vid bilorus'kyx', Zapysky Cyna Sv. Vasylija Velykoho, VI, 1-2, L'viv, 1935, p. 264.

7) Zurawski, op cit., p. 85.

8) In the following discussion the period before the Union of Lublin (1569) will be considered. The conventional cut-off year is 1577. Although the situation did not change drastically through at least the first half of the 17 th century some circumstances did. Therefore it is advisable to treat the two periods separately. (Many arguments in Aničenka's book referred to in note 2 are blurred by the lack of distinction between the two periods.)

9) A specimen of the regional approach to the literature of the period is Z. Florczak's Udziat regionów w ksztattowaniu się piśmiennictwa polskiego XVI wieku, Warsaw, 1967. Nothing of the kind has been done for $\mathrm{Br}$ and U literature.

10) Arxiv Jugo-zapadnoj Rossii, p. I, vol. 7, Kiev, 1887; Universitetskie izvestija, 10, Kiev, 1904.

11) 'Po preobladaniju $v$ nem èlementov belorusskoj reči, i nazyvat' ego sleduet belorusskim jazykom.' (E. Karskij, 'Cto takoe drevnee zapadnorusskoe narečie?', Trudy po belorusskomu i drugim slavjanskim jazykam, Moscow, 1962, pp. 253-62 (p. 262).)

12) C. S. Stang, Die westrussische Kanzleisprache des Grossfürstentums Litauen, Oslo, 1935, pp. 26, 50. 
13) Espoused e.g. by L. Humec'ka. See her 'Voprosy ukrainsko-belorusskix jazykovyx svjazej drevnego perioda', Voprosy jazykoznanija, 1965, 2, 43, and by myself in 1953 (J. Serech, Problems in the Formation of Belorussian, New York, p. 59) (but revised in 1956, see my Teasers and Appeasers, Munich, 1971, pp. 249f.).

14) The contrast between ChSl and Rth in their relation to $U$ as drawn here is somewhat simplified. ChSl in its local recensions also admitted some substitutions; but as long as one remains within Eastern Slavic territory they were of a narrower range and at least in spelling much less systematically applied.

15) This resulted in the frequent appearance of $e$ instead of the real, historical $\check{e}$ in substantives ending in original -ěnie derived from verbs in -ěti as terpěti: terpernie, cf. such spellings in obviously $U$ texts as rozumenie in the Peresopnycja Gospel (1556-1561) (Trudy 3 arxeologičeskogo s"ezda $v$ Rossii, 2, Kiev, 1878, p. 83), poveleniju in the Ostrih Bible (1581) (quoted after G. Freidhof, Vergleichende sprachliche Studien zur Gennadius-Bibel (1499) und Ostroger Bibel (1580/81), Frankfurt a.M., 1972, p. 76). These are not lexical borrowings from $\mathrm{Br}$ but the result of the flight from the 'new $\check{e}$ ', only ultimately - 'through orthographic convention - conditioned by the $\mathrm{Br}$ patterns.

16) It should be established, however, if these regular substitutions were applied in the entire Ukraine or only in its non-Lithuanian part. It seems that the Volhynians rather often endeavored to retain the $\mathrm{Br}$ pattern intact, especially in relation to $\check{e}$, even against their own pronuncia'cion. And the closer we come to the end of the period the stronger is the adherence to the $\mathrm{Br}$ pattern. Very typical in this respect is the Testament of Vasyl' Zahorovs'kyj, a Volhynian (district Volodymyr), the Castellan of Braclav (1577). The text systematically uses $e$ for $\check{e}$ and only such slips as kopěju 'copy' acc sg, pryjatelě nom pl, špytalě acc pl (Arxiv Jugo-zapadnoj Rossii, I, 1, Kiev, 1859, pp. 74, 86, 89) betray 'that Zahorovs'kyj's real pronunciation was not identical with $e$. If these observations are correct one may speak of two lines in the development of Rth as the standard secular language in the Ukraine: gradual emancipation of the non-Lithuanian (Western) Ukraine from it; and gradual surrender of Polissian U (including Volhynia) to it in its basic, North Central Br form. Zuhaj was a Western Ukrainian, no doubt; where the 'Kievan' copy of the Lithuanian Status was written, we do not know.

17) Cf. an analogous statement in Slovnyk staroukrajins'koji movy XIV-XV vv. Probnyj zošyt, Kiev, 1964, p. 8.

18) Rozov, op cit., no. 22, p. 42; I. Bogdan, Documentele lui Ştefan cel Mare, 2, Bucharest, 1913, p. 497.

19) With a sound value first of closed $e$ and then $i$, which was, however, not confused with the old $i$ because the latter by that time had become $y$.

20) Quoted after G. Kryžanovskij, Volynskie Eparxial'nye vedomosti, 1886, No. 17-18, p. 120; and I. Kernyc'kyj, O. Kupčyns'kyj ed., Akty sela Odrexovy, Kiev, 1970, p. 45.

21) But in preambles of otherwise U charters kažnyj occurs in a cliché phrase 'znamenito kažnomu dobromu činimъ' (e.g. Rozov, op. cit., no. 82, p. 152) the same as another cliché of $\mathrm{Br}$ chanceries, in transference of propert: acts, na veki večnye occurs with $e$ in the charters which otherwise make a strict distinction beween $\check{e}$ and $e$ under stress (e.g. Rozov, op. cit., no. 77, p. 142).

22) See examples in Aničènka, op. cit., p. 223.

23) Not automatically though: the scribe should also have known the rules of alternation, e.g. $o$ in perfective verbs vs. $a$ in the imperfective (iterative) ones as in uhoditi: uhažati, etc. That knowledge seems to have died out in our days: Aničènka, p. 149 pass. takes such spellings with a for a manifestation of akan'e! Apparently to publish a book in Slavic historical linguistics acquaintance with Old ChSl (or even Polish for that matter) is no longer required. 
24) Arxiv Jugo-zapadnoj Rossii, VII, 1, p. 131.

25) As published by A. Veselovskij, SbORJaS, 44, 1888.

26) As published by N. Tupikov, PDPiI, 140, 1901.

27) As published by V. Peretc, PDPiI, 150, 1903.

28) As published by E. Karskij, IORJaS, 2, 1897.

29) See A. Sobolevskij in SbORJaS, 74, 1903, pp. 413, 419. Published by M. Speranskij, PDPiI, 171, 1908 and V. Peretc, Filolohičnyj zbirnyk pamjati K. Myxal'ćuka, Kiev, 1915.

30) As partly published by P. Žytec'kyj in Trudy 3 arxeologičeskogo s"ezda $v$ Rossii 2, Kiev, 1878 (The Peresopnycja Gospel); and described by I. Ohijenko, Sbornik $v$ čest na prof. L. Miletič, Sofia, 1933 (The Verba Gospel).

31) This movement of the $\mathrm{Br}$ population can be clearly seen in the data of the ljustraciji of Žytomyr, Kiev, Kaniv and Cerkasy, 1552, see AJuZR, VII, 1 , pp. 80f, 85, 87f, 101, 103f, 112, 114, 116,147. An eloquent illustration of how deep $\mathrm{Br}$ influence (directly or through $\mathrm{Rth}$ ) was can be seen in the faci that in Armenian documents written in Qipçaq in Kamjanec' Podil's'kyj (1562-1566) one encounters along with numerous Ukrainianisms individual $\mathrm{Br}$ forms, e.g. mesta 'town'. See T. Grunin, ed., Dokumenty na poloveckom jazyke XVI v. (Sudebnye akty kamenec-podol'skoj armjanskoj obščiny), Moscow, 1967, pp. 174, 196, 213.

32) Described and partly published by V. Peretc, Issledovanija i materialy po istorii starinnoj ukrainskoj literatury XVI-XVIII vekov, 2, Leningrad, 1928 (SbpRJas, 1).

33) The general type of its language, insofar as Ohijenko's description and the scanty fragments published by him allow us to judge, is Br; Ukrainianisms are more departures than substitutions; limited in number, they still are too numerous to be simply discarded (see on the new $\check{e}, \mathbf{p}$. 258, on confusion of $i$ and $y, \mathrm{pp}$. 268f, on confusion of $\check{e}$ and $i, \mathrm{p} .239$, although not all examples are pertinen't). If it is not a $\mathrm{U}$ copy from a $\mathrm{Br}$ text (which seems not to be very plausible for chronological and cultural reasons) the text should have been written by a $\mathrm{Br}$ dwelling in a $\mathrm{U}$ area and partly affected by $U$ speech. At any rate the significance of the text for the history of $U$ is limited.

34) W. Kuraszkiewicz was aware of that in 1934 (see his Gramoty halickowotyńskie XIV-XV wieku, Kraków, p. 49).

35) Archiwum ksiqżą Lubartowiczów Sanguszków w Sławucie, 1, L'viv, 1887, pp. $46,62 f$. 